\title{
Correlation between temporal-spatial parameters and manual ability of adults with dyskinetic cerebral palsy
}

Correlação entre os parâmetros espaçotemporais e a habilidade manual de adultos com paralisia cerebral do tipo discinético

Correlación entre los parámetros espacio-temporales y la habilidad manual de adultos con parálisis cerebral tipo discinética

Mariana Cunha Artilheiro', Danielli Souza Speciali', Bárbara Alves Lopes², João Carlos Ferrari Correa', Paulo Roberto Garcia Lucareli'

\begin{abstract}
IThe aim of this study was to verify relation between kinematic variables of temporal-spatial parameters and manual ability and between own temporal-spatial variables during the movement of bring a mug to the mouth in adults with dyskinetic cerebral palsy (DCP). Sixteen adults with DCP were evaluated by MACS (Manual Ability Classification System), and by temporal-spatial variables of tridimensional kinematics of the movement to bring a bug to the mouth by means of 9 cameras infra-red Vicon ${ }^{\circ} \mathrm{MX}$ 40 (Oxford Metrics Group, Oxford, UK). The Spearman correlation coefficient $(\rho)$ was used to correlate variables. As a result, we found weak correlation between the classification of manual ability and the adjusting phase $(\rho=0.219)$, the velocity variables - average velocity $(\rho=-0.313)$, peak velocity ( $\rho=-0.282)$ and time to peak velocity $(\rho=-0.250)$. No correlation was found between the variables going and returning phase and MACS. Moderate correlation was found between going and returning phase ( $\rho=0.559)$, between the going phase and time to peak velocity ( $\rho=0.518$ ) and between the adjusting phase and peak velocity ( $\rho=-0.562$ ). A strong correlation was found between the mean velocity and peak velocity ( $\rho=0.947)$ and between the adjusting phase and average velocity ( $\rho=-0.635$ ). In conclusion, functional impairment may be related to longer adjusting phase and decrease of movement speed in subjects with PCD. Kinematic variables were related to
\end{abstract}

each other in moderate and strong way and indicated that the phases runtime influences the movement speed. Keywords I Cerebral Palsy, Young Adult; Dyskinesias; Upper Extremity.

RESUMO I O objetivo deste estudo foi verificar se existe relação entre as variáveis cinemáticas espaçotemporais e a habilidade manual e entre as próprias variáveis espaçotemporais estudadas durante o movimento de levar uma caneca à boca em indivíduos adultos com paralisia cerebral do tipo discinético (PCD). Dezesseis adultos com PCD foram submetidos à avaliação da habilidade manual por meio da escala MACS (Manual Ability Classification System) e análise das variáveis espaçotemporais da cinemática tridimensional do movimento de levar uma caneca à boca por meio de 9 câmeras de infravermelho Vicon" MX 40 (Oxford Metrics Group, Oxford, UK). O coeficiente de correlação de Spearman ( $\rho$ ) foi aplicado para verificar relação entre as variáveis estudadas. Como resultado, foi encontrada fraca correlação entre a classificação da habilidade manual e a fase de ajuste do movimento $(\rho=0,219)$, as variáveis de velocidade - velocidade média $(\rho=-0,313)$, velocidade máxima $(\rho=-0,282)$ e tempo para atingir o pico de velocidade $(\rho=-0,250)$. Não foi encontrada correlação entre a variável tempo de ida e a variável tempo de retorno do movimento e a MACS. Correlação moderada foi encontrada entre a fase de ida e a fase de retorno do movimento $(\rho=0,559)$, entre a

PPostgraduate Program of Rehabilitation Sciences at Universidade Nove de Julho (UNINOVE) - São Paulo (SP), Brazil. 2Physical Therapy at UNINOVE - São Paulo (SP), Brazil. 
fase de ida e o tempo para atingir o pico de velocidade $(\rho=0,518)$ e entre a fase de ajuste e a velocidade máxima ( $\rho=-0,562)$. Forte correlação foi encontrada entre a velocidade média e o pico de velocidade $(\rho=0,947)$ e entre a fase de ajuste e a velocidade média ( $\rho=-0,635)$. Como conclusão, o prejuízo funcional pode ser relacionado ao maior tempo de execução da fase de ajuste e com a redução da velocidade do movimento em indivíduos com PCD. As variáveis cinemáticas se relacionaram de maneira moderada e forte e indicaram que o tempo de execução das fases influencia a velocidade do movimento.

Descritores I Paralisia Cerebral; Adulto Jovem; Discinesias; Extremidade Superior.

RESUMO I El objetivo de este estudio fue verificar si hay una relación entre las variables cinemáticas espacio-temporales y la habilidad manual y entre las propias variables espacio-temporales estudiadas durante el movimiento de traer una taza a la boca en adultos con parálisis cerebral tipo discinética (PCD). Dieciséis adultos con PCD fueron sometidos a una evaluación de habilidad manual por medio de la escala MACS (Manual Ability Classification System) y análisis de las variables espacio-temporales de la cinemática tridimensional del movimiento para llevar una taza a la boca por medio de 9 cámaras infrarrojas Vicon ${ }^{\circledR}$ MX 40 (Oxford Metrics Group, Oxford, UK). El coeficiente de correlación de Spearman ( $\rho$ ) fue aplicado para verificar la relación entre las variables estudiadas. Como resultado, fue encontrada una débil correlación entre la clasificación de la habilidad manual y la fase de ajuste del movimiento $(\rho=0,219)$, las variables de velocidad - velocidad media $(\rho=-0,313)$, velocidad máxima $(\rho=-0,282)$ y tiempo para alcanzar la velocidad máxima $(\rho=-0,250)$. No se encontró correlación entre la variable tiempo de ida y la variable de regreso del movimiento y la MACS. Correlación moderada se encontró entre la fase de ida y la fase de regreso del movimiento $(\rho=0,559)$, entre la fase de ida y el tiempo para alcanzar la velocidad máxima $(\rho=0,518)$ y entre la fase de ajuste y la velocidad máxima ( $\rho=-0,562$ ). Fuerte correlación se encontró entre la velocidad media y la velocidad máxima $(\rho=0,947)$ y entre la fase de ajuste y la velocidad media $(\rho=-0,635)$. A modo de conclusión, el perjuicio funcional puede ser relacionado con más tiempo de ejecución de la fase de ajuste y con la reducción de la velocidad del movimiento en sujetos con PCD. Las variables cinemáticas se relacionaban de manera moderada y fuerte e

Palabras clave I Parálisis Cerebral; Adulto Joven; Discinesias; Extremidad Superior.

\section{INTRODUCTION}

The dyskinetic cerebral palsy (DCP) is characterized by the presence of involuntary, uncontrolled and recurring movements, which are occasionally stereotyped, representing one of the most incapacitating forms of the disease due to severe motor compromise ${ }^{1}$. The involuntary movement can lead to discomfort, interfere in voluntary movements, limit and even prevent upper limb (UULL) functions, which results in worse performance of activities of daily living (ADL), such as clothing, diet and personal hygiene, once the reach, the prehension and the manipulation are damaged ${ }^{2}$.

The functional compromise of UULL in adults with DCP is little described in literature. Studies indicate there is abnormal muscle activity resulting from the simultaneous and sustained contraction of the agonist and antagonist muscles during the motor act, thus generating difficulties to maintain the linear trajectory and the high variability of movements ${ }^{3}$, which also makes it more difficult to learn motor skills of the upper limb (UL) ${ }^{4}$.

The clinical assessment of the UULL movement should be specific, contemplating measurement instruments that are common in the physical therapy practice. The Manual Ability Classification System (MACS)

scale $^{5}$ is used to classify how children and young adults with cerebral palsy handle objects during ADL.

In order to assess the movements quantitatively, the kinematic analysis has been considered as a potential instrument to measure clinical results, thus contributing with the demonstration of functional activities, such as the movements involved in the action of bringing a glass towards the mouth. These actions are performed by patients with UL dysfunction ${ }^{6}$.

Therefore, due to the lack of results coming from measuring instruments used in clinical practice that may be compared with the quantitative evaluation provided by kinematics, this study aimed at verifying if there is a relationship between kinematic temporalspatial variables and manual ability, and also between the temporal-spatial variables analyzed during the action of bringing a mug towards the mouth among adults with DCP.

\section{METHODOLOGY}

This is a cross-sectional study conducted in the Laboratory of Motion Studies in Hospital Israelita Albert Einstein, in São Paulo (SP), Brazil. All of the participants signed the informed consent form; the study 
was approved by the Research Ethics Committee of UNINOVE (n. 429636/2011).

The sample was calculated based on the variable curvature index related to the linear parameters of the softness of movements, since it is believed that this variable can indicate changes in the patients' movements, when compared to the movements of healthy volunteers. A $0.05 \alpha$ and $80 \%$ power were adopted. In order to reach this power, the need for 14 individuals with DCP was observed during sample calculation.

Volunteers diagnosed with DCP were selected from a list of patients assisted in the Cerebral Palsy Outpatient clinic in the Rehabilitation Center Lar Escola São Francisco, from 2009 to 2011. Fifty-nine patients were included for being able to move the UL voluntarily (right or left-handed) during the requested task, and for being able to understand simple verbal commands. Out of these, 43 were excluded for presenting associated diseases, for having been submitted to previous surgical procedures in the UULL, or for presenting with functional incapacity in the UULL; therefore, 16 participants were submitted to the evaluations.

\section{Protocol and instrumentation}

Initially, the manual ability of the UL considered to be dominant by the volunteers was assessed and classified by the MACS scale. The action of bringing a mug towards the mouth was also filmed, in order to verify the prehension skill of the volunteers and to complete the manual ability analysis. All of the individuals were questioned as to the ability to handle objects and execute tasks that are present in their daily manual activities and/or if it was necessary to ask for help or supervision to perform them. The questions were addressed to 13 volunteers who were able to answer them voluntarily. However, three participants demonstrated they were not able to answer the questions, therefore, they were addressed to their caretakers. The scale has five levels: the lowest one indicates less manual motor limitation, and the highest one suggests dependence for $\mathrm{ADL}^{5}$.

For the capture of the movement and the acquisition of temporal-spatial kinematic data, volunteers were placed on a chair with adjustable back and height, which enable to place the ankles, knees and hips at approximately $90^{\circ}$, as standard ${ }^{7}$. Two Velcro stripes crossed anteriorly to the thorax were placed to keep stability and to contain the synergic trunk movements. The dominant UL was supported on a table to the front; the shoulder was at a neutral position, the elbow was flexed at $90^{\circ}$ and the forearm in pronation, while the non-dominant UL was placed throughout the body.

A cylindrical mug $(10,70 \mathrm{~cm}$ high and $8 \mathrm{~cm}$ in diameter) filled with $50 \%$ of its total volume, in order to simulate the liquid content, was placed $75 \%$ from the total UL range, with a stabilized trunk.

Volunteers were told to transport the mug with the dominant UL towards the mouth (going phase), simulate the task of drinking water (adjustment phase) and returning the glass to the initial position (return phase). Six consecutive movements were performed at a comfortable speed, and the patient could not let go of the glass during each repetition. One attempt was allowed for practice minutes before data acquisition.

As part of the kinematic instrumentation, volunteers were also submitted to anthropometric measurements (height, weight, distance between the acromion and the humerus greater tubercle, elbow and fist diameter, hand thickness), which were requested to calculate the biomechanical model and to obtain the studied variables.

For the acquisition of kinematic data, 24 retroreflective spherical markers, with $14 \mathrm{~mm}$, were fixated with a hypoallergenic double-sided tape on anatomic landmarks, placed on 4 areas of the head, in the spinous process of the seventh cervical vertebra, in the scapula, in the spinous process of the tenth thoracic vertebra, between the posterior superior iliac spines, in the manubrium and in the sternal body, in anterior superior iliac spines, in the acromion, in the lateral epicondyles, in the radial and ulnar styloid processes and in the proximal phalanx of the third fingers.

The model originally described by Rab et al. ${ }^{8}$ was used as a reference to form the segments head, trunk, pelvis, arms, forearms, hands and the middle phalanx of the third fingers (Figure 1).

Kinematic data were captured by 9 infrared Vicon ${ }^{\circledR}$ MX 40 cameras (Oxford Metrics Group, Oxford, UK) with a $120 \mathrm{~Hz}$ capture frequency. The reconstruction and the processing of the markers position in the tridimensional volume were made with the Vicon ${ }^{\circledR}$ Nexus software.

For the quantitative assessment of the movement, the following temporal-spatial parameters were studied: time to execute the going, adjustment and return phases and the speed of the movement, divided into mean speed, maximum speed (peak velocity) and time to reach peak velocity, which is determined between the onset of the going phase and the time when the maximum peak velocity is reached. 


\section{Statistical analysis}

Data from the 16 selected and assessed volunteers were used for statistical analysis, without the occurrence of sampling loss. The verification of data distribution was conducted by the Kolmogorov-Smirnov test. The Spearman's correlation test ${ }^{9}$ was applied to correlate the score obtained in the MACS scale with the temporal-spatial variables, and also to relate the different temporal-spatial variables. As an indicator of poor correlation, the Spearman's correlation coefficient $(\rho)$ was considered between 0.20 and 0.39 ; for the moderate correlation, between 0.40 and 0.59 ; and for the strong correlation, higher than $0.59^{10}$. A significance level (p) of 0.05 was also adopted. Analyses were conducted by the software SPSS ${ }^{\circledR}$, version 15.0.

\section{RESULTS}

The sample characteristics as to age (mean and standard-deviation), gender, manual dominance and score in MACS are descriptively presented in Table 1 . As to the MACS classification, 4 out of the 16 volunteers obtained 4 points, which indicates the need for adaptations concerning manipulation or continuous support and/or adapted equipment, even for the partial performance of the activity. Three volunteers got three points, which means performance is low and limited in relation to the quality and quantity of movement; there is also the need for help to prepare and/or change the activity. Finally, nine volunteers were classified with two points, which demonstrates manipulation is made with less quality and lower speed, and that there is some difficulty to perform the movement.

The correlation analysis between the total score of MACS and the temporal-spatial variables showed a poor positive correlation between the classification of manual ability and the adjustment phase of the movement $(\rho=0.219)$, suggesting that volunteers with high scores in the scale took longer in the adjustment phase. A poor negative correlation was found between the MACS score and speed variables - mean velocity $(\rho=-0.313)$, maximum velocity $(\rho=-0.282)$ and time to reach peak velocity $(\rho=-0.250)$, which suggests that volunteers with higher scores in the scale move with reduced velocity in relation to volunteers with low scores (Table 2).

The score in MACS was not correlated, however, with the times in the going and return phases, which shows that manual ability does not influence the time of excursion from bringing the mug to the mouth and returning it to the table.

Even though the MACS score was poorly related to the temporal-spatial variables, these were moderately and strongly correlated. A positive moderate correlation was found for the going and returning phase of the movement $(\rho=0.559)$, and for the going phase and the time to reach peak velocity $(\rho=0.518)$, showing a tendency of the time to execute

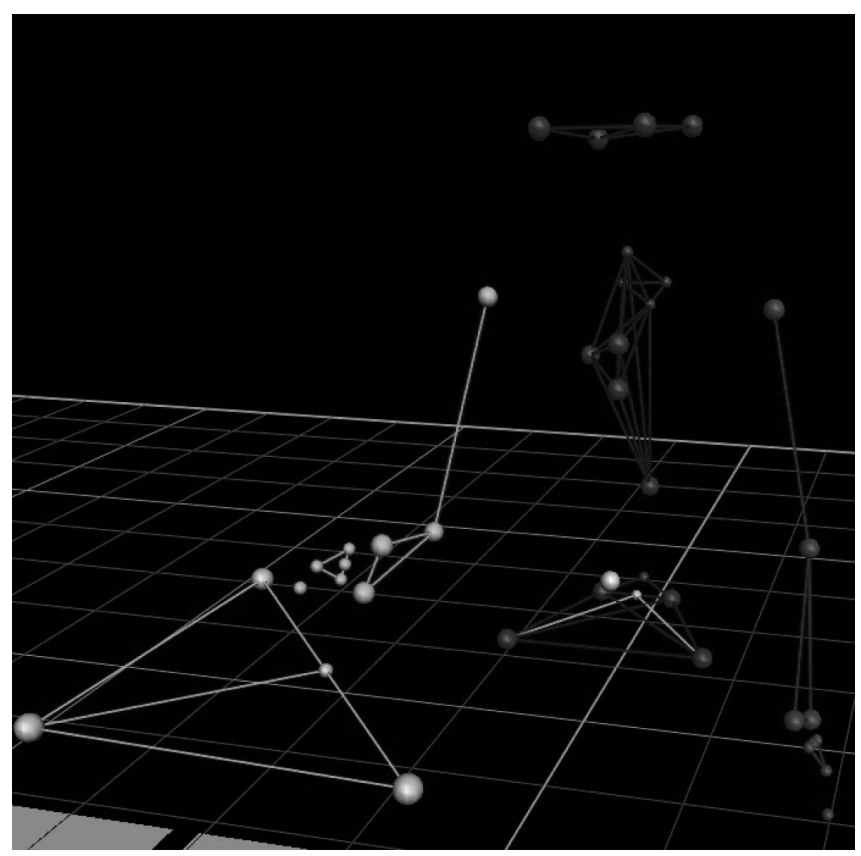

Figure 1. Representation of the position of markers used to collect kinematic data, based on the model by Rab et al. ${ }^{8}$

Table 1. Characteristics of the sample as to age, described in mean and standard-deviation, gender, manual dominance and score in the Manual Ability Classification System (MACS), presented descriptively.

\begin{tabular}{|c|c|c|c|c|}
\hline Patients (DCP) & Age (years) & Gender & Dominance & MACS \\
\hline 1 & 29 & Male & Left & II \\
\hline 2 & 31 & Male & Left & $\|$ \\
\hline 3 & 24 & Male & Left & $\|$ \\
\hline 4 & 27 & Female & Left & $\|$ \\
\hline 5 & 23 & Male & Right & IV \\
\hline 6 & 32 & Male & Left & IV \\
\hline 7 & 29 & Female & Left & $\|$ \\
\hline 8 & 25 & Male & Right & IV \\
\hline 9 & 37 & Male & Left & III \\
\hline 10 & 47 & Female & Left & IV \\
\hline 11 & 27 & Female & Right & $\|$ \\
\hline 12 & 26 & Male & Left & III \\
\hline 13 & 29 & Male & Right & $\|$ \\
\hline 14 & 37 & Male & Right & $\|$ \\
\hline 15 & 30 & Female & Left & $\|$ \\
\hline 16 & $\begin{array}{c}21 \\
29.62(3.42)\end{array}$ & $\begin{array}{l}\text { Female } \\
(6 \mathrm{~F} / 1 \mathrm{OM})\end{array}$ & $\begin{array}{c}\text { Left } \\
(5 \mathrm{R} / 11 \mathrm{~L})\end{array}$ & $\begin{array}{c}\text { III } \\
(9-I I ; 3-I I I ; 4-I V)\end{array}$ \\
\hline
\end{tabular}

DCP: dyskinetic cerebral palsy; F: female; M: male; R: right; L: left 
the going phase to determine the time to reach peak velocity and return in the movement. The adjustment phase was moderately and negatively correlated with maximum velocity $(\rho=-0.562)$, which indicates that the longer the time spent for the adjustment phase, the lower the peak of velocity for the movement. A strong positive correlation was found between mean velocity and peak of velocity $(\rho=0.947)$. Finally, a strong negative correlation was found between the adjustment phase and mean velocity $(\rho=-0.635)$, showing that, even though the ability is poorly related with the adjustment phase, it has a strong association with mean velocity (Table 2 ).

\section{DISCUSSION}

It is essential to measure the functional movements of UULL, since it provides information about how the tasks are performed. Some scales were developed with the objective of assessing the function of the UL movement only among children with cerebral palsy, qualitatively, and these provide a subjective description by means of scores based on observational assessments of the motor performance during the execution of tasks.

The tridimensional kinematics of the UULL is technically more challenging, due to the great complexity of the shoulder joint movement ${ }^{11}$. However, biomechanical models for UL have been used ${ }^{8,12}$, and studies that assess functional tasks with the use of this tool have been described in literature for the infant population with cerebral palsy, mostly in the hemiparetic spastic type, for being more prevalent ${ }^{13}$.

Since there are a few studies in literature correlating the methods of qualitative and quantitative evaluation of the movement in the population with the dyskinetic type, this study aimed at verifying a possible correlation between the quantitative kinematic variables and the qualitative manual ability during the action of bringing a mug towards the mouth among adults in the analyzed population.

The hypothesis was that volunteers with higher MACS score would execute the phases of the task slower, with reduced velocity. Even though a poor relation was found, it was observed that the highest MACS score, which indicates more severe functional compromise, is related to the longer period to execute the adjustment phase. The requested movements at this phase are related to more accuracy when compared to the others. In the adjustment phase, the mug should reach the mouth successfully, and, to increase the movement precision, this task may take longer to be concluded ${ }^{3}$. As expected in the study hypothesis, a higher functional compromise of MACS was also related with lower mean velocity, maximum velocity and time to reach peak velocity. The latter presents a tendency to follow-up the values resulting from mean velocity, and its slower duration may indicate slowness to elaborate the strategy to take the mug towards the mouth, since this speed variable was analyzed on the going phase of the movement.

It is believed that the poor relations can be related to factors that are inherent to the absence of a similar distribution of the number of volunteers in the sample in the levels of the scale (nine volunteers were scored on level II, and the others were on levels III and IV). Arner et al. ${ }^{14}$ showed that volunteers with DCP can be classified in five levels, being mostly concentrated on levels IV and V, and that the scale is an indication for the changes in manual function and independence in manual activities. Butler et al.15 also classified children

Table 2. Spearman's correlation coefficient ( $\rho$ ) between the score in the Manual Ability Classification System (MACS) and the variables of time and speed of the movement for volunteers with dyskinetic cerebral palsy

\begin{tabular}{|c|c|c|c|c|c|c|c|}
\hline & MACS & $\begin{array}{l}\text { Going phase } \\
\text { (s) }\end{array}$ & $\begin{array}{l}\text { Adjustment } \\
\text { phase (s) }\end{array}$ & $\begin{array}{l}\text { Return phase } \\
\text { (s) }\end{array}$ & $\begin{array}{l}\text { Mean velocity } \\
(\mathrm{m} / \mathrm{s})\end{array}$ & $\begin{array}{l}\text { Peak velocity } \\
(\mathrm{m} / \mathrm{s})\end{array}$ & $\begin{array}{l}\text { Time to reach } \\
\text { peack velocity (s) }\end{array}$ \\
\hline MACS & (1) & $(-0.094)^{¥}$ & $(0.219)^{*}$ & (O) & $(-0.313)^{*} ¥$ & $(-0.282)^{* 7}$ & $(-0.250)^{*}$ \\
\hline Going phase & $(-0.094)^{*}$ & (1) & $(0.024)^{*}$ & $(0.559)^{\star \star \varepsilon}$ & $(-0.062)^{*}$ & $(-0.029)^{*}$ & $(0.518)^{\star \star \varepsilon}$ \\
\hline Adjustment phase & $(0.219)^{\star ¥}$ & $(0.024)^{*}$ & (1) & $(0.082)^{*}$ & $(-0.635)^{k+* \xi \xi}$ & $(-0.562)^{\star \star £}$ & $(-0.026)^{*}$ \\
\hline Return phase & 0 & $(0.559)^{\star \star \varepsilon}$ & $(0.082)^{*}$ & (1) & $(0.026)^{*}$ & $(0.035)^{*}$ & $(0.388)^{\star *}$ \\
\hline Mean velocity & $(-0.313)^{\star *}$ & $(-0.062)^{*}$ & $(-0.635)^{* \star \star \S}$ & $(0.026)^{*}$ & (1) & $(0.947)^{\star * \star \S}$ & $(0.229)^{* *}$ \\
\hline Peak velocity & $(-0.282)^{\star *}$ & $(-0.029)^{*}$ & $(-0.562)^{\star \star £}$ & $(0.035)^{*}$ & $(0.947)^{\star \star \star \S}$ & (1) & $(0.197)^{¥}$ \\
\hline Time to reach peak elocity & $(-0.250)^{* \neq}$ & $(0.518)^{\star \star \Sigma}$ & $(-0.026)^{*}$ & $(0.388)^{\star *}$ & $(0.229)^{\star *}$ & $(0.197)^{*}$ & (1) \\
\hline $\begin{array}{l}\text { Median } \\
(|Q|)\end{array}$ & $\begin{array}{c}2 \\
(2.00-3,75)\end{array}$ & $\begin{array}{c}1,403 \\
(1,029-1,721)\end{array}$ & $\begin{array}{c}1,022 \\
(0,5258-2,436)\end{array}$ & $\begin{array}{c}1.81 \\
(1,463-2,694)\end{array}$ & $\begin{array}{c}0,3221 \\
(0,2708-0,4923)\end{array}$ & $\begin{array}{c}0,5567 \\
(0,4299-0,8761)\end{array}$ & $\begin{array}{c}0,4667 \\
(0,3795-0,5634)\end{array}$ \\
\hline
\end{tabular}

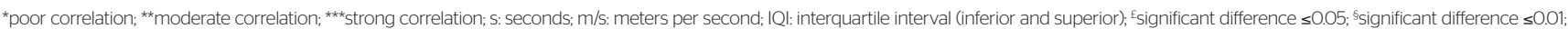
*non-significant difference $\geq 0.05$ 
with DCP with lower scores (I, II and III), and observed that patients who presented more severe compromise had higher scores in MACS, and took longer to execute the analyzed task.

It is important to consider the interference of involuntary movements, which is a characteristic of the disease, on the variability of performance, due to the inability to exclude the unwanted components from the movement trajectory ${ }^{1}$. Therefore, motor behaviors that do not follow an execution pattern for the same task may result in interference in the variables of velocity an time of execution; these are compared with the MACS score, and they may reflect a poor relation. Besides, there is also the fact that the same MACS score can include the same functional ability, but different motor skills. The lack of motor homogeneity in each score may have interfered in the analysis of relation between the measuring variables and the result in poor relations.

The analyses between the analyzed kinematic variables resulted in moderate and strong relations, regardless of the manual ability classification. In a moderate and positive way, relations between the going and returning phase of the movement and between the going phase and the time to reach peak velocity indicate the fact that the going phase influenced the return movement, and the elaboration of a strategy to bring the glass to the mouth. The adjustment phase, which was previously pointed out as the precision phase, was negatively and moderately related with maximum velocity, and negatively and strongly related with mean velocity, which corroborates the hypothesis of decreased velocity for movements that require more precision ${ }^{3}$. Strongly and positively, mean and maximum velocities (expressed by the peak velocity) were related, as expected.

The findings in this study cooperate with the knowledge about the manual function and with the decision making concerning the therapeutic objective of the physical therapist or occupational therapy in the rehabilitation of UULL of adults with DCP. The tridimensional analysis is an important tool for making clinical decisions about the adopted therapeutic technique ${ }^{16-17}$. However, it is often not available as a routine evaluation, unlike MACS, which represents a clinical scale that is easy to apply and does not require previous training ${ }^{5}$. It proved to be an alternative to suggest that higher scores can be related to compromised performances for functional UULL activities with relation to the analyzed temporal-spatial variables.

As study limitations, it is possible to point out that movements in the acromioclavicular, scapulothoracic and sternoclavicular joints were not analyzed individually, due to the complexity of arm movements and also because the movements of the trunk were restrained during the task. Besides, the restriction in trunk movements, despite isolating the UL movement, does not reproduce a functional condition. Even though the most used procedure for the collection of kinematic data is the use of retroreflective markers over the skin, using bone prominences as reference, the artifacts of the movements of soft tissues over the bones cannot be excluded ${ }^{18}$.

\section{CONCLUSION}

The analysis between functional ability during the movement of bringing a mug towards the mouth and the kinematic variables is able to suggest that the functional compromise can be related to the longer time of execution of the adjustment phase, and to the reduced movement velocity among individuals with DCP. The analysis between kinematic variables showed a positive relation between the going and the returning phase of the movement, between the going phase and the time to reach peak velocity, and between mean velocity and peak velocity. A negative relation was observed between the adjustment phase and mean and maximum velocities. These findings enable to indicate that the time of execution of phases influences the movement velocity.

\section{REFERENCES}

1. Himmelmann K, Hagberg G, Wiklund LM, Eek MN, Uvebrant P. Dyskinetic cerebral palsy: a population based study of children born between 1991 and 1998. Dev Med Child Neurol. 2007;49(4):246-51.

2. Shumway-Cook A, Woollacott MH. Constraints on motor control: an overview of neurologic impairments. In: Shumway-Cook A, Woollacott $\mathrm{MH}$. Motor Control: Translating Research into Clinical Practice. $4^{\text {th }}$ ed. New York: Elsevier; 2010.

3. Sanger TD. Arm trajectories in Dyskinetic Cerebral Palsy have increased ramdom variability. J Child Neurol. 2006;21(7):551-7.

4. Arnould C, Penta M, Renders A, Thonnard J. ABILHAND-kids: a measure of manual ability in children with cerebral palsy. Neurology. 2004;63(6):1045-52.

5. Ealisson AC, Krumline-Sundholm L, Rösblad B, Beckung E, Arner M, Öhrvall AM, et al. Classification System (MACS) for children with cerebral palsy: scale development and evidence of validity and reliability. Dev Med Child Neurol. 2006;48(7):549-54.

6. Reyes-Guzmán A, Gil-Agudo A, Peñasco-Martín B, Solís-Mozos M, del Ama-Espinosa A, Pérez-Rizo E. Kinematic analysis of the daily activity 
of drinking from a glass in a population with cervical spinal cord injury. J Neuroeng Rehabil. 2010;7:41-8,

7. Jaspers E, Feys H, Bruyninckx H, Cutti A. Harlaar J, Molenaers G, et al. The reliability of upper limb kinematics in children with hemiplegic cerebral palsy. Gait Posture. 2011;33(4):568-75.

8. Rab G, Petuskey K, Bagley A. A method for determination of upper extremity kinematics. Gait Posture. 2002:15(2):113-9.

9. Barbetta P. Estatística aplicada às ciências sociais. Florianópolis: Ed UFSC; 2006

10. Mitra A, Lankfort S. Research methods in park recreation and leisure services. Champaign: Sagamore; 1999

11. Rau G, Disselhorst-Klug C, Schmidt R. Movement biomechanics goes upwards: from the leg to the arm. J Biomech. 2000;33(10):1207-16.

12. Mackey AH, Walt SE, Stott NS. Deficits in Upper-limb task performance in children with hemiplegic cerebral palsy as defined by 3-dimensional kinematics. Arch Phys Med Rehabil. 2006;87(2):207-15.

13. Himmelmann K, Hagberg G, Beckung E, Hagberg B, Uverbrant P. The changing panorama of cerebral palsy in Sweden. IX. Prevalence and origin in the birth-year period 1995-1998. Acta Paediatr. 2005;94(3):287-94

14. Arner M, Eliasson AC, Nicklasson S, Sommerstein K, Hägglund G. Hand function in cerebral palsy. Report of 367 children in population-based longitudinal health care program. J Hand Surg Am. 2008;33(8):1337-47.

15. Butler EE, Ladd AL, Louie SA, Lamont LE, Wong W, Rose J. Threedimensional kinematics of the upper limb during a Reach and Grasp Cycle for children. Gait Posture. 2010;32(1):72-7.

16. van Andel CJ, Wolterbeek N, Doorenbosch CA, Veeger DH, Harlaar J. Complete 3D kinematics of upper extremity functional tasks. Gait Posture. 2008:27(1):120-7.

17. Mackey AH, Walt SE, Lobb GA, Stott NS. Reability of upper and lower limb three-dimensional kinematics in children with hemiplegia. Gait Posture. 2005;22(1):1-9.

18. Cutti AG, Paolini G, Troncossi M, Cappello A, Davalli A. Soft tissue artefact assessment in humeral axial rotation. Gait Posture. 2005;21(3):341-9. 